\title{
Epistemological Diversity in Social Science Graduate Curriculum: The Experience from an American College in Czech Republic
}

Sosyal Bilimler Lisansüstü Programlarında Epistemolojik Çeșitlilik: Çek Cumburiyetindeki Bir Amerikan Kolejinin Deneyimi

PELIN AYAN MUSIL

Anglo-American University

Received: 16.04.15 | Accepted: I2.06.15

\begin{abstract}
The insufficient coverage of philosophy of science and epistemological discussion in graduate curriculum has been a subject of criticism among several scholars. In this article, I examine the ways through which the MA curriculum in International Relations in an American college in Czech Republic was restructured toward a meaningful representation of different epistemological approaches. The restructuration of the program comes as a result of the university's search for legitimacy in a post-communist society. Similar to its peers in Central and Eastern Europe, the university is enforced to increase its quality in teaching. It does so through introducing participatory curriculum committees where faculty members from different epistemological backgrounds gather. The experience shows that such participatory mechanisms in universities are essential to give space for philosophy of science debates in graduate curriculum.
\end{abstract}

Keywords: Epistemology, philosophy of science, social sciences, international relations, graduate curriculum. 
[University teacher] stands in the service of 'moral' forces; he fulfills the duty of bringing about self-clarification and a sense of responsibility. And I be-

lieve he will be the more able to accomplish this, the more conscientiously he avoids the desire personally to impose upon or suggest to his audience his own stand. (Max Weber)

\section{Introduction}

Max Weber in his famous speech, Science as Vocation (I922), addressed how immoral of a teacher it would be if he imposed his own personal political view on his students. Underlying part of Weber's thoughts on the role of a teacher was his knowledge and experience in leading the students to develop their own worldviews. The variety of approaches on the foundations of knowledge in social sciences brings forth a similar question. How moral is it to imprint one's own epistemological view on a group of students who have no prior knowledge of existing paradigms in social science research? Indeed, it would be wrong to state that the decision to 'imprint' or 'not to imprint' solely belongs to the teacher today when it is the institutions that started making such choices. In most cases, hiring faculty is already administered in accordance with the institution's own approach to epistemology.

According to a research in the US a decade ago, $\mathrm{PhD}$ program requirements did not give much choice to lecturers anyway simply because the programs already targeted at teaching within the realm of certain approaches. Shwartz-Shea's (2003) review of top 57 doctoral programs in Political Science in the US has shown that the depth of coverage of the philosophy of science was very limited. The domination of quantitative methods in these programs was clearly visible while the epistemological diversity in qualitative research, most importantly between qualitativepositivism and qualitative-interpretivism was not equally presented to the students.

Similarly, several Master's level programs in International Relations (IR) lack meaningful discussions on epistemology. A basic investigation of the randomly selected Io universities from the US and Europe offering Master's level programs in IR or equivalent disciplines show that they concentrate on one single trend in IR rather than providing a compre- 
hensive combination of different schools of thought. ${ }^{I}$ It is possible to observe that the relevant departments in these universities have separated their programs with respect to their epistemological approaches: ${ }^{2}$ In other words, they offer either: (I) a program heavily based on interpretivism and critical approaches, (2) a program that emphasizes positivism and empiricism, or (3) multiple programs distinguished along different epistemological perspectives. Thus, finding a single program that represents various approaches to science and knowledge is rarity in IR-related Master's programs.

It should yet be noted that the omission of epistemology is partly due to the time pressures of fitting into a single course. The increasing array of methodological choices particularly in positivism and quantitative research has made the extensive coverage of epistemological approaches a laborious option, particularly in $\mathrm{PhD}$ programs (Mayer, 2002: I24). On the other hand, including all alternative epistemological approaches in a Master's program of Political Science/Politics/International Relations may be a more convenient option. Having a basic background in 'what epistemology is' and 'why it matters,' an MA graduate can more consciously make a choice among various $\mathrm{PhD}$ programs considering their fields of epistemological specialization. Besides, designing an MA curriculum with epistemological diversity may equally be useful for those graduates that do not want to continue with further studies but remain in the practical arena: Being aware of epistemological diversity and training in different approaches would make them complete thinkers in the policy-making field.

Thus, the next question would be how to achieve epistemologically

\footnotetext{
I The investigation was the initiative of the Curriculum Committee of the School of International Relations at Anglo-American University in Prague. It was undertaken in March 2014 during the restructration process of its own MA program through an examination of the websites of the programs. The randomly selected programs are from Aberystwyth University (UK), University of Copenhagen (Denmark), Georgetown University (USA), Harvard University (USA), London School of Economics (UK), Lund University (Sweden), Central European University (Hungary), University of Amsterdam (The Netherlands), University of Birmingham (UK), Humboldt University and Frei Universitat in Berlin (Germany).

2 The exceptions are Lund University and Central European University. The former offers courses on the 'theory of sciences' whereas the latter covers the epistemological discussion in two different research methods courses.
} 
diverse MA programs? In this respect, I would like to present the experience of a small-sized American college in Czech Republic, AngloAmerican University. Main impetus for change in this college was the establishment of a participatory curriculum committee, representing faculty from diverse epistemological backgrounds. Before sharing this experience, I would like to provide the context of higher education system in general in Central and Eastern Europe in order to show the motivation of private colleges for establishing such curriculum committees.

\section{The Private Higher Education in Central and Eastern Europe}

During the communist era, research on social science was severely constrained due to political factors in Central and Eastern European (CEE) countries. The dissolution of the Soviet Union in I99I has been a critical juncture after which they entered a phase of radical transformation in higher education. The number of private universities rapidly increased as the gross enrollment ratio in these countries doubled after the fall of communism (Slantheva, 2007: 56).

However, the Soviet system also left its legacies on the institutional landscape of higher education system (Wenninger, 2010): Pre-I989 period was characterized by a split between research carried out at the academies of sciences and teaching based at the universities. The division resulted in a two-tier system in which leading research was performed at the academies and universities basically remained as teaching institutions. Yet, post-communist societies are in general hesitant to accept private provision of higher education, having historically placed more reliance on the state to be the caretaker of private goods (Slantcheva, 2007). Private universities and their faculty members are negatively perceived by government, compared to public universities and large sectors of the population in terms of the capacity of research they can deliver (Reisz, 2003: 24; Galbraith, 2003). That is why the number of doctoral programs offered in private universities is quite rare and the premier level of education is mostly limited with Master's level degree programs.

Other problematic issues shared by most Central and Eastern European countries are the double or triple jobbing as a consequence of poor remuneration in research and teaching sector in social science (Wen- 
ninger, 20IO). For instance, most of the staff at research-based academies engages with teaching at private universities as a part-time job. The private universities whose survival and sustainability are quite dependent on student tuitions benefit more from the presence of adjunct faculty as they deprive them of the tax burden. In this sense, private universities often work with a limited number of permanent faculty members.

As a result of these problems, private universities in CEE have been in search for sources of legitimacy. Most common characteristics include a focus on the quality of teaching. Different forms of pedagogical and technical innovation are often emphasized along with a promise to produce skilled, flexible, and critically thinking labor force (Pachuashvili, 2007: 62). In this way, they distinguish themselves from the public universities and the academies where the major scientific research is produced. Yet, while they are academically free to design the content and structure of the study programs, these study programs are still subject to accreditation, which is granted mostly by the Ministry of Education (i.e. in Czech Republic, it is the Accreditation Commission of the Ministry). ${ }^{3}$

However, state is no longer the sole source of legitimacy. International and donor organizations have also become important in providing legitimacy to private universities in CEE (Pachuashvili, 2007: 77). In addition to responding to accreditation requirements of the state authorities, private universities are now seeking accreditation from international unions of colleges. These processes then affect the internal decisionmaking mechanisms of these universities, fostering an intellectual debate among the faculty (both including permanent and adjunct faculty) coming from diverse backgrounds about 'how to make students complete thinkers,' and 'how to engage them with social science research.' Despite the aforementioned challenges the private universities face in a postcommunist culture, their interaction with international donor institutions provide excellent opportunities to them in developing representative, participatory curriculum committees.

3 "Study in the higher Education System" Study in Czech Republic http://www.studyin.cz/higher-education-system. 


\section{Transformation of an MA Program in IR: The Experience of the Anglo- American University}

Anglo-American University (AAU) in Prague is among the 44 private universities existing in Czech Republic, going through exactly the same process with its peers in the CEE region. It was founded in 1990, shortly after the collapse of communism with a vision to create an educational institution that would combine the American and British academic principles with Central European traditions. ${ }^{4}$ It is a teaching oriented university, trying to legitimize its position in Czech society and beyond, through advertising the quality of teaching, student learning and the teaching skills of the faculty trained in various universities from the US, Australia, Western and Central Europe.

The main goal of the MA Program in International Relations and Diplomacy is to prepare students not only for post-graduate study but also for employment in an international dimension where a high level of professionalism is required (such as international organizations, relevant government or private sector jobs, think-tanks, NGOs). ${ }^{5}$ To this end, the knowledge-structure of the program emphasizes understanding the history, current events and institutional framework of international relations as well as the structure of global political economy. The skill-oriented part of the program emphasizes international communication, negotiation strategies and diplomacy skills. As a two-year program comprising of 6o American credits, it includes two foundational courses, Theories of International Relations (3 credits) and Advanced Research Methods (3 credits). The compulsory courses are comprised of Theories of Globalization, International Political Economy, International Organizations, International Development, International Law, Conflict Studies, Diplomatic Protocol and Negotiations.

The prevailing characteristics of the MA students in International Relations and Diplomacy have been as follows: The number of students ranges from 40 to 50 every academic year and represent different nationalities (mainly Czechs and Slovaks but also Americans, Germans, Geor-

4 Anglo-American University (AAU) website, http://www.aauni.edu.

5 AAU Catalogue 20II/2OI2. 
gians, Russians, Kyrgyz's, Kazakhs, Uzbeks, and to a lesser degree Turks, Greeks, Armenians, and Nigerians). Many of the MA students have fulltime jobs, which are not necessarily related with IR issues. Their previous knowledge of theories of social science and academic research is also limited.

Every five years, the university applies for re-accreditation of its MA program to the Ministry of Education of the Czech Republic, on which the survival and sustainability of the program is highly depended. ${ }^{6}$ In order to increase its sources of legitimacy in Czech Republic and beyond, the university has sought accreditation within Western Association for Schools and Colleges (WASC) in 20Ir. Having fulfilled the eligibility criteria in 2013 for accreditation, the university administration, faculty and program contents were subject to a tight scrutiny process by this association. The most important change this process brought was the impact on internal decision-making mechanisms of the university. The abundance of the hierarchic approach to curriculum development has been replaced with the newly established participatory curriculum committee that has been composed of the school deans, department chairs, faculty members and the students in discussing the weaknesses and strengths of the existing programs.

It was also for the first time in the curriculum committee of the MA program in International Relations and Diplomacy that the faculty discussed the issue of academic pluralism. ${ }^{7}$ Composed of three interpretivists and three positivist scientists with different specializations such as comparative politics, IR theories, international political economy and European studies, the committee met I2 times from the beginning of 2012 to April 20I4. The epistemological diversity among the faculty was noted as a potential strength but it was also observed that the disorder in the sequence of course listings, contents of foundational courses and the curriculum structure were not sufficient in giving the ability of thinking through the lenses of different epistemologies to students. For instance,

6 Personal communication with the top-level representative of the academic management, 20 March 2013.

7 Report of the $\mathrm{I}^{\text {st }}$ Curriculum Committee Meeting of the School of International Relations and Diplomacy at AAU, I March 2012. 
the one course on methodology -POL 59I Advanced (Qualitative) Research Methods- was taught in a qualitative-positivist manner whereas in another foundational course -POL 600 Theories of International Relations- students were trained by interpretivist scholars and encouraged to create qualitative-interpretivist research designs.

The interpretevist and positivist faculty members taught their elective courses from their epistemological point of view. The absence of a "philosophy of science" lecture further limited the discussion of epistemological approaches in the classroom. The result was that the students did not properly learn which approach to prefer in writing their MA theses. Among several formal and informal consultations with students on weaknesses of the program, anonymous student's comment was striking:

Due to the positivist focus in the methodology class where we actually learned how to design a research, I am more comfortable staying in the positivist "sphere" (in the class we were encouraged to take a different approach, but I did not feel we really learned how to, or what that might entail - or at least not to the extent we did so for the more positivist research designs). I still would have a very hard time designing a (more) interpretivist research and would feel much less confident in my efforts. I think that as a result of that class, I also have very positivist ideas about what would pass as a "scientific enough" research design. I think that's a pity, because more critical analysis is something that would interest me (MA student, 2I March 2OI4).

As a result of these problematic issues detected both by the faculty and students, the learning outcomes of the MA Program in IR were reformulated by the curriculum committee, which emphasized that "students should be able to understand and utilize information, situate their arguments (as well as arguments they encounter from others) within the general ontological and epistemological frameworks of the field."

The foundational courses and particularly the course on Advanced (Qualitative) Research Methods was strengthened with an equal discussion of the existing epistemologies by means of inclusion of interpretivist guest lecturers that teach how to design interpretivist research (see Table I to see the change in the syllabus content). Similarly, it was decided that

8 Formally adopted in the Curriculum Committee Meeting, 8 April 2014. 
the Thesis Seminar course should be taught with the inclusion of both positivist and interpretivist instructors. Finally, the required and elective courses were categorized and re-ordered, in accordance with their level of concentration on these approaches so that they are equally and meaningfully covered.

\begin{tabular}{|c|c|c|}
\hline & $\begin{array}{l}\text { Prior to the Restructuration } \\
\text { of the MA Program in IR }\end{array}$ & $\begin{array}{l}\text { After the Restructuration of the } \\
\text { MA Program in IR }\end{array}$ \\
\hline $\begin{array}{l}\text { Relevant } \\
\text { Program } \\
\text { Learning } \\
\text { Outcomes }\end{array}$ & $\begin{array}{l}\text { Have specialized knowledge } \\
\text { of theories of international } \\
\text { relations, diplomatic history, } \\
\text { international economy, in- } \\
\text { ternational law and conflict } \\
\text { studies. }\end{array}$ & $\begin{array}{l}\text { Situate their arguments within the } \\
\text { general ontological and epistemo- } \\
\text { logical frameworks of International } \\
\text { Relations; apply relevant methods, } \\
\text { theories, and levels of analysis in } \\
\text { building arguments. }\end{array}$ \\
\hline $\begin{array}{l}\text { Syllabus } \\
\text { Content } \\
\text { for "Re- } \\
\text { search } \\
\text { Methods" } \\
\text { Course }\end{array}$ & $\begin{array}{l}\text { Language of the research, } \\
\text { deductive and inductive rea- } \\
\text { soning, concept formation, } \\
\text { measurement validity, pro- } \\
\text { cess-tracing, controlled-com- } \\
\text { parison, possibility principle, } \\
\text { typological theory, macro- } \\
\text { historical comparison, quali- } \\
\text { tative comparative analysis } \\
\text { (crisp sets) }\end{array}$ & $\begin{array}{l}\text { Foundations of knowledge, main } \\
\text { paradigms in social science re- } \\
\text { search, language of the positivist } \\
\text { research, language of the interpre- } \\
\text { tivist research, deductive, inductive } \\
\text { and abductive reasoning, process- } \\
\text { tracing, comparative case studies in } \\
\text { positivist research, discourse analy- } \\
\text { sis in interpretivism, approaches to } \\
\text { data collection/analysis in positiv- } \\
\text { ism and interpretivism, examples of } \\
\text { interpretivist and positivist re- } \\
\text { search designs }\end{array}$ \\
\hline
\end{tabular}

Table I: Some Changes in the MA Program in IR toward Epistemological Diversity

In the newly designed Advanced Research Methods course, which was made compulsory for the second or the third semester of the program, students were asked to write weekly memos through which they were made to think through the lenses of both interpretivism and positiv- 
ism. An example of a memo question from the $2013 / 2014$ academic year is as follows:

How can we know that an international crisis exists? How would the interpretivist and positivist paradigms approach to the knowledge of international crisis? Compare the two epistemological approaches on the example of studying international crises as a subject.

Through such questions, the students could see the main differences between the main two approaches. On the other hand, the newly introduced Thesis Seminar -compulsory course in the final semester of their studies- helped students write their thesis proposals by means of applying one of these approaches to the conduct of their research.

\section{Conclusion}

While considering the MA curriculum as a basis of covering the epistemological diversity, a very careful program structuration is necessary with the participation of faculty coming from different epistemological backgrounds. An MA program designed in this way can also be considered as a potential preparatory stage for a doctoral program that offers a single epistemological focus. The point is to make prospective $\mathrm{PhD}$ students aware of different paradigms in social science research before they choose an institution of doctoral study. The graduates of the discussed MA program at Anglo-American University have started exploring the options in this way and consult the faculty about the availabilities while making their decisions.

\section{References}

Galbraith, K. (2003). Towards Quality Private Higher Education in Central and Eastern Europe. Higher Education in Europe, 28 (4), 539-559.

Mayer, L. (2002). The Centrality of Epistemology in Methodology Education. PS: Political Science and Politics, 35 (I), I2I-I25.

Pachuashvili, M. (2007). Legitimacy Sources and Private Growth in the PostCommunist Context. Private Higher Education in Post-Communist Europe in Search for Legitimacy (eds. S. Slantcheva \& D. C. Levy). New York: Palgrave Macmillan, 75-94.

Reisz, R. D. (2003). Public Policy for Private Higher Education in Central and 
Eastern Europe. Conceptual Clarifications, Statistical Evidence, Open Questions. HoF Arbeitsbericht. Wittenberg: Institute for Higher Education Research at the Martin Luther University Halle Wittenberg.

Slantcheva, S. (2007). Legitimating the Difference: Private Higher Education Institutions in Central and Eastern Europe. Private Higher Education in PostCommunist Europe in Search for Legitimacy (eds. S. Slantcheva \& D. C. Levy). New York: Palgrave Macmillan, 55-74.

Schwartz-Shea, P. (2003). Is This the Curriculum We Want? Doctoral Requirements and Offerings in Methods and Methodology. PS: Political Science and Politics, 36 (3), 379-386.

Weber, M. 1946 [1922]. Science as Vocation. From Max Weber: Essays in Sociology (eds. H. H. Gerth \& C. W. Mills). New York: Oxford University Press, I29156.

Wenninger, A. (2010). Social Sciences in Central and Eastern Europe: Institutonal Landscapes. Internationalization of Social Sciences in Central and Eastern Europe (eds. I. P. Kov \& I. Palne \& D. Kutsar). New York: Routledge, 85-98.

Öz: Sosyal bilimlerde lisansüstü müfredatın yeterli derecede bilim felsefesi ve epistemolojik tartıșma içermemesi bir çok kez eleștiri konusu olmuștur. Bu makalede, Çek Cumhuriyetindeki bir Amerikan kolejinde yer alan Uluslararası Ilișkiler yükseklisans programının farklı epistemolojik yaklașımları içerecek șekilde nasıl geliștiği incelenmektedir. Müfredatın yeniden yapılandırılması, üniversitenin komünizm sonrası toplumda meșruiyet arayıșının bir sonucu olarak ortaya çıkmıștır. Orta ve Doğu Avrupa'daki muadillerine benzer bir șekilde, öğretim kalitesini artırma zorunluluğu içinde olan üniversite, farklı epistemolojik yaklașımlardan gelen öğretim üyelerinin katıldığı program komiteleri olușturmuștur. Bu deneyim göstermektedir ki, üniversitelerin katılımcı platformlar olușturmaları, bilim felsefesinde yer alan tartışmaların lisansüstü programlarda daha etkin yer almasını sağlamaktadır.

Anahtar Kelimeler: Epistemoloji, bilim felsefesi, sosyal bilimler, uluslararası ilișkiler, lisansüstü müfredat. 